\title{
Fostering Students' Environmental Care Characters Through Local Wisdom-Based Teaching Materials
}

\author{
Asrial $^{1 *}$, Syahrial ${ }^{2}$, Maison ${ }^{3}$, Dwi Agus Kurniawan ${ }^{4}$, Embarianiyati Putri ${ }^{5}$ \\ 1,2,3,4 Faculty of Teacher Training and Education University of Jambi, Jambi, Indonesia \\ ${ }^{5}$ Elementary School Teacher Education, University of Jambi, Jambi, Indonesia \\ e-mail: porigih@gmail.com ${ }^{1}$, syahrial.karea@gmail.com ${ }^{2}$, maison@unja.ac.id ${ }^{3}$, $\underline{\text { dwiagus.k@unja.ac.id }}$,
} embarianiyatiputri@gmail.com ${ }^{5}$

\begin{abstract}
This study aims to describe teaching materials based on local wisdom in fostering a character of environmental care in students. Local wisdom can be interpreted as a local culture that guides life. The problem in this study refers to the teaching materials used by teachers based on local wisdom in fostering character in students. The method used for this research is qualitative by using observation, interview, and documentation techniques. The results of the analysis of teaching material needs based on local wisdom are analyzing teaching materials for class V SD which includes aspects of mapping Core Competencies and Basic Competencies. In conclusion, analyzing the need for local wisdom-based teaching materials, such as teaching materials that have a variety of materials that can be integrated with local wisdom, can activate students in learning, the need to develop teaching materials based on local wisdom.
\end{abstract}

Keywords: teaching materials, local wisdom, character

\section{Introduction}

School is a formal forum for seeking knowledge and knowledge and character building must be sensitive to the surrounding environment. One of them can be seen from the teaching materials used in the learning process. Teaching materials are components that must exist, because teaching materials are used as learning tools for students (Nurafni et al., 2020). Teaching materials means learning tools that contain materials, methods and learning media used by the teacher. In line with (Damanik et al., 2014), teaching material is a tool that must exist and be made systematically containing three main points, namely objectives, material, and evaluation. With the aim that students easily understand and understand the material presented. Good teaching material means that it is in accordance with the curriculum, student conditions and student needs in the field. In addition, in delivering material the teacher also needs a media so that the delivery is easily understood and absorbed by students (Oktariyani \& Juwita, 2019). Through the media, learning messages become easier to understand and more interesting. Good learning media means that it can increase learning motivation, and it is fun so that students don't feel bored when learning takes place.

Based on the results of the previous research, the development of teaching materials based on local wisdom is developed to overcome difficulties experienced at school, teachers can use local wisdom-based teaching materials as a source that can be used in learning (Indrawini \& Widiati, 2017). To overcome the difficulties of inadequate teaching materials, teachers should develop teaching materials in accordance with the competencies that students must master based on the demands of the curriculum, student characteristics and the conditions in which the teacher teaches. With the availability of adequate teaching materials, it is hoped that learning can run efficiently and effectively and in the end can improve student learning outcomes. Whereas in this study, the problem is almost the same, namely about teaching materials based on local wisdom, which is integrated with a tradition called "betangas tradition" which after being analyzed can be integrated into class V Elementary Schools which can foster a caring character for the environment in students.

\footnotetext{
${ }^{*}$ Corresponding author.

Received 29 July 2020; Accepted 23 September 2020; Available online 01 March 2021

(C) 2020 JPI. All Rights Reserved
}

Jurnal Pendidikan Indonesia (JPI) | 152 
The curriculum is a guideline or reference in preparing, designing, methods and making learning objectives in educational units (Latif et al., 2019). It can be said that the curriculum is the basic guideline in every educational unit that must exist and be applied so that the learning device can be in accordance with what is designed. In line with this, the curriculum is a set of subjects and educational programs provided by an educational provider which contains lesson plans that will be given to students, lessons in one period of education level (Wiratni, 2017). The curriculum must always be updated in line with changes in order to remain relevant according to the times. The learning system in the 2013 curriculum is designed in an integrated manner between one subject and another in the form of themes or commonly known as thematic learning (Khusna et al., 2018). With thematic learning teachers are required to be creative and innovative in delivering subject matter so that students don't feel bored when learning by applying scientific approaches such as; observation, asking questions, digging up information, and communicating (presenting) what they get or know from what they learn so that students understand the lesson well, are more active and creative and create various learning experiences for students. In implementing the 2013 Curriculum, teachers are required to master ICT in learning and be able to use it (Aryanto et al., 2019). One of them is by using learning videos such as interactive videos, power points and so on. With the development of ICT increasingly sophisticated, the global demands that we have to face are making education to adapt technological developments to efforts to improve the quality of education, especially adjusting its use for the world of education, especially in the learning process (Budiman, 2017). ICTs can also act as teachers or tutorials, and can be used as an infinite number of reference books. The role of ICT as a bridge between teachers and students in the implementation of learning process activities.

Regulation of the Minister of Education and Culture No. 22 of 2016 concerning the standard process that learning in elementary schools accommodates integrated thematic learning, in aspects of cultural diversity can be integrated in the context of learning by incorporating local wisdom content. So that a teacher is required to have the ability to design teaching materials based on local wisdom. Local wisdom is local richness that contains rules or life viewpoints. Local wisdom has function as the way to shape human beings to be wiser in their lives. It has similar notion with character education (Shaleha \& Purbani, 2019). Local wisdom can be interpreted as a local culture that contains rules that can serve as guidelines for a better life. Local wisdom can be interpreted as values that exist in society that can become rules in everyday life (Sumardjoko \& Musyiam, 2018). Real environmental learning in preserving the environment is obtained by students through the life around them. Surrounding life that can support environmental preservation is through local wisdom.

Local wisdom is a characteristic that comes from districts or areas that have cultural values developed in local communities from generation to generation (Priyambodo \& Wulaningrum, 2017). The existence of local wisdom can foster an understanding so that we have regional characteristics that are hereditary that must be preserved by the nation's children so that they are not eroded by external cultures. Local wisdom is often linked with local culture, rules and knowledge (Sulistyani et al., 2017). This is in accordance with Appendix IV of Regulation of the Minister of Education and Culture Number 81A of 2013 that learning at elementary level schools is developed thematically, integrating across subjects to develop attitudes, skills and knowledge and appreciating local cultural diversity. Local wisdom is very closely related to traditional culture in a place, usually local wisdom contains a view or rules so that people have a foothold in determining an action in daily life (Rachmadyanti, 2017). In addition, local wisdom can not only improve education, but discipline, mutual cooperation, cultural preservation and care for the environment. The local wisdom which can be used to increase the welfare includes hard work, discipline, education, health, mutual aid or cooperation, gender management, culture creativity and preservation, and environment care (Nouban \& Abazid, 2017).

The betangas tradition is a traditional tradition that exists in Mandiangin sub-district, Sarolangun district. This betangas tradition is usually carried out for future brides for the purpose of health and wasting sweat. The ingredients used are spices such as lemongrass, kaffir lime leaves, and fragrant pandan leaves, then boil all of these ingredients so that they 
can give off a distinctive and fragrant aroma. Betangas uses ingredients derived from plants that are useful in medicine and have a very fragrant aroma (Utri et al., 2017). The first way of implementing it is to prepare all the materials and tools. The two forms of the mat become a circle, then the bride and groom enter the mat and cover it with a blanket on top without the slightest bit. The three tasks of the bride and groom in the mat are stirring the boiled water of the spices so that they can emit a fragrant and distinctive aroma and sweat. By utilizing or cultivating local wisdom is part of preserving and protecting it from extinction by integrating the "betangas tradition" into elementary school learning. To know and get to know the customs and culture of the local area. Like cultivating traditional betangas spices, namely lemongrass leaves, fragrant pandan leaves and kaffir lime leaves. Behaviors that show concern for the environment in environmental conservation can be realized by the efforts of teachers to combine or unify real conditions with material (Immaniar et al., 2019). One of them is by integrating teaching materials with local wisdom in the local area. The attitude of caring for the environment contained in the betangas tradition based on interviews with the Mandiangin traditional leader is to preserve the spices that are the ingredients for the betangas tradition. Attitudes and actions that always try to prevent damage to the surrounding natural environment, and develop efforts to repair natural damage that has occurred (Priyatna, 2016). By participating in preserving and cultivating the traditions that exist in the area.

Environmental care character education is an effort to instill character values in students in the form of a caring attitude towards the environment in order to create patterns of thought and behavior sustainable living (Fitriasari, 2017). By being environmentally friendly, it will affect the development of children to have good character. Character education has been integrated in the curriculum, therefore teachers are able to integrate character education and curriculum without assigning new subjects (Muhtar \& Dallyono, 2020). That is the importance of character to be taught to students in order to have good morals for their future. Character education is a concept that involves every aspect of family life, school community, and society that supports the development of positive character in each individual (Damayanti \& Nurgiyantoro, 2018). In increasing the character of caring for the environment in students these three aspects are very much needed, where in the family the parents play a role in shaping the character of their children, in the school aspect it can help shape the character of caring for the environment to increase sensitivity and concern for the environment, and in the aspects of society when children interacting with the community environment must be adjusted to the stage of their development, because the community environment will affect the development and growth of children.

This research is important to do, motivated by several things, namely first, many teachers do not yet know the importance of integrating local wisdom in learning in elementary schools, to foster a character that cares about the environment in students and preserves culture because customs are beginning to be eroded by outside culture. The focus of the problem in this study only refers to the teaching materials used by teachers related to local wisdom that can foster a caring character for the environment such as cooperation in preserving the spices of Betangas traditional ingredients and maintaining the culture in the local area.

\section{Method}

This research is a qualitative research that uses qualitative data such as interviews, participant observation data and document data to understand and explain the social phenomenon (Azmi et al., 2018). Usually using a phenomenological approach, namely research that intends to understand the phenomena experienced by research subjects. Such as behavior, perception and action and others holistically, and in a descriptive way in the form of words or language in a specific natural context and by utilizing the scientific method. This study uses a type purposive sampling (sample aim) to take information sources (informants) based on predetermined intentions. Where this research takes research subjects which include three traditional informants from one traditional figure, one community leader and one class teacher. Qualitative research is a research method used to examine natural object conditions. according to the type of research used, the research approach chosen is a descriptive 
approach. Based on the problems studied and aims to analyze the phenomena that occur in the field.

Techniques used by this researcher were three, namely interviews, observation, and documentation. First, data obtained through in-depth interviews (in-depth) using questions open-ended. The data obtained are in the form of perceptions, opinions, feelings and knowledge. The second is data obtained through observation. The data obtained are in the form of images in the field in the form of attitudes, actions, talks, interpersonal interactions and others. The third is a document. Documents in the form of written material stored. Before going to the field data analysis was carried out. The results of preliminary studies in the form of documentation, books, works, photos, and other materials that are thought to be related to the problem to be studied are very decisive, especially in determining the focus of the research. The analysis technique carried out in this study uses the Miles and Huberman model and is modified according to the needs of the researcher which consists of three main components, namely data reduction, data presentation and drawing conclusions as follows, first, data reduction is part from analysis that sharpens, classifies, directs, removes unnecessary, and organizes data in such a way that conclusions can finally be drawn and verified relating to the object to be studied, namely local wisdom (betangas tradition) (Ahyar et al., 2020). Second, data presentation is a set of structured information that gives the possibility of drawing conclusions and taking action. In this research, it was conducted by selecting data that was more relevant to the research context. Third, drawing conclusions and verification are new findings that have never existed before. Findings can be in the form of descriptions or descriptions of an object that was previously dim or dark so that after being examined it becomes clear, it can be in the form of a causal or interactive relationship, hypotheses or theories related to the object of research about local wisdom (betangas tradition) in the bathangin.

\section{Results and Discussion \\ Results \\ Preliminary study interview results}

Researcher conducted a preliminary study on fifth grade elementary school teachers. This interview was conducted in the office during a break. Interviews were conducted to find out problems in elementary schools regarding teaching materials, ICT, and electronic modules based on local wisdom with Erlina Efliani, a class VB teacher at SD Negeri 64/1 Muara Bulian. The results of the interviews obtained were that in the learning process activities using ICT media were very useful for educators and students, the positive impact made students interested in the learning process, more interesting and not monotonous. The learning outcomes obtained by students using ICT media have increased and students are more enthusiastic. Information and Communication Technology (ICT) is a medium used to improve human ability to communicate both in the school environment and in the community (Sinulingga et al., 2019). In these schools there is no learning based on local wisdom, it's just that there are local contents such as regional dance. Selection of the right media is one of the steps that every teacher must really pay attention to, because it does not rule out the application of wrong or inappropriate media in accordance with the material being taught, will be an obstacle in understanding the material taught by the teacher to these students (Hikmah et al., 2016). Teaching materials that are often used when learning, such as mathematical content, image media such as making cube nets from cardboard on practical IPA loads such as conduction heat transfer, on IPS loads such as students making observations to stalls to get information about the results of buying and selling interactions. And on sbdp loads usually make crafts. The response to the electronic module based on local wisdom is very good to be taught and developed to elementary school children, to increase student interest in learning, and to preserve and introduce local wisdom that exists, especially in Jambi Province itself. The hope is that the electronic module can be applied to learning because it will have a positive impact on students and educators, so that all of us can preserve and maintain the existing culture and not be easily influenced by external cultures. 
The results of an interview regarding local wisdom (betangas tradition) with Mr. Muhammad Zain who is the customary leader of Mandiangin sub-district, Sarolangun regency. The result of the interview obtained was that the betangas tradition is a traditional tradition that exists in the Mandiangin sub-district, with the aim of eliminating sweat, keeping the body healthy and scent the body. The meaning of betangas is closed which gives off hot steam. Betangas tradition in each area has the same name and the same time is carried out the day before the marriage contract. Opinions about local wisdom (betangas tradition) are included in elementary school learning, it's a good and creative idea so that students know and participate in preserving existing local wisdom. Local wisdom can come from the culture of the community in a certain locality (Afiqoh et al., 2018). From a historical-ographic perspective, local wisdom can form a local history. In addition, it can foster a caring character for the environment such as cooperation in preserving the spices of the Betangas tradition and maintaining the culture in the local area.

The results of interviews regarding local wisdom (betangas tradition) with Ibu Ulyati who is a Koran teacher and expert in betangas, in Mandiangin Village. The result of the interview obtained was that the betangas tradition is a traditional custom to clean the bride-tobe or what is called a steam bath to remove dirty sweat using spices such as kaffir lime leaves, betawi lemongrass and pandan leaves. So from the betangas tradition it means sweating so that your clothes and clothes don't smell bad. Betangas tradition in each area has the same name and the same time is carried out the day before the marriage contract. This tradition has been around since ancient times as a hereditary tradition. Local culture has a very close relationship with the community in an environment with all natural conditions in that environment (Setyaningrum, 2018). If local wisdom is incorporated into elementary school learning, it will be very interesting and can contribute to preserving and maintaining local culture. Because local wisdom can be said to be a cultural identity that needs to be introduced to the young generation through education because it is the local young generation who will be able to defend their own area.

\section{Documentation}

The following is a picture of the documentation regarding the Betangas tradition and learning in elementary schools.

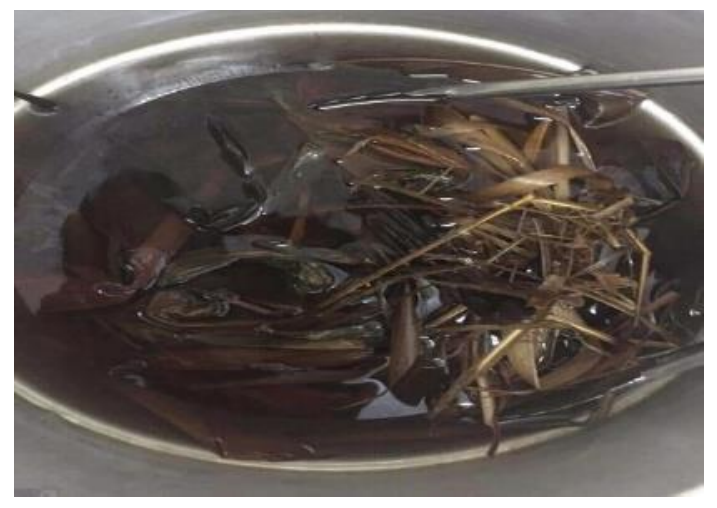

Figure 1. Boiled water for spices for betangas

Figure 1 is a picture of boiled water used for the betangas tradition. The spices used are such as lemon grass leaves, fragrant pandan leaves and kaffir lime leaves. Because these types of leaves can give off a distinctive and fragrant aroma. 


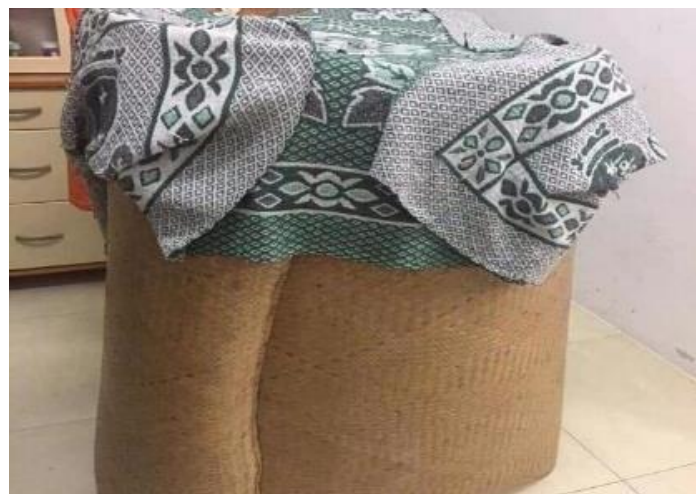

Figure 2. The process of the betangas tradition

Figure 2 is a picture of the process of the betangas tradition carried out by the bride and groom. To carry out a tradition that has been passed down from generation to generation in Mandiangin sub-district. With the aim to sweat and body health.

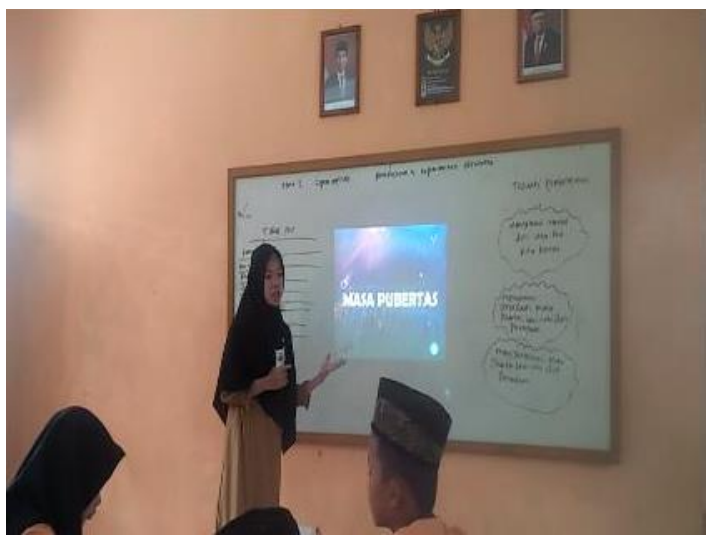

Figure 3. The learning process using ICT

Figure 3 is the process of learning science content using power point media. Students feel happy and active when learning takes place.

\section{Discussion}

The foundation of local wisdom theory is based on the socio-cultural theory by Vigotsky. Socio-cultural theory is a theory that emphasizes that the social environment can help the learning process (Lestariningsih \& Suardiman, 2017). This theory assumes that society and culture can be used as a source of knowledge. One of them is by preserving local wisdom. Based on previous research, the development of thematic teaching materials based on local wisdom is developed to overcome difficulties experienced in schools (Indrawini \& Widiati, 2017). The difficulty is in the form of inadequate availability of teaching materials in accordance with local environmental conditions. The development of teaching materials based on local wisdom is adjusted to the competencies that students must master based on the demands of the curriculum. In the research that has been carried out, there are several findings that have been previously described. These findings are summarized in the formulation of the problem, namely that many teachers do not yet know the importance of integrating local wisdom in learning in elementary schools, to foster a character that cares for the environment of students entitled "Analysis of Local Wisdom-Based Teaching Materials to Improve Character Care for the Environment in Students" many teachers do not yet know the importance of integrating local wisdom into learning in elementary schools, to foster a character that cares for the environment in students and preserve culture because customs are beginning to be eroded by external culture. The results analyze the need for teaching materials based on local wisdom, 
namely analyzing teaching materials for grade V SD which includes aspects of mapping Core Competencies and Basic Competencies, material suitability with KD and suitability of learning activities. Teaching materials based on local wisdom will be more useful if it does not only contain local cultural values but is also able to improve survival skills needed in the 21 st century (Santosa et al., 2019). Therefore, teachers must be able to integrate learning with existing local wisdom, not only centered on student books. However, it can be innovated so that learning is more interesting (Riwu et al., 2018). By integrating learning with local wisdom, so that learning becomes active, developing self-potential in maintaining and preserving existing local wealth.

Regulation of the Minister of Education and Culture No. 24 of 2016 concerning basic competencies and core competencies which are already in the teacher's book theme 6 (Heat and Its Transfer) sub-theme 1 (Temperature and Heat) in learning (Indonesian and IPA). Basic competence is the ability to achieve core competencies that students must acquire through learning. In each formulation of basic competencies there are elements of thinking and material abilities. Competency standards for graduates are the main source of achievement for all subjects at a certain level. The following is a table regarding basic competencies and knowledge that becomes a reference or guide for teachers in teaching in accordance with the objectives achieved. The science learning process in elementary schools should provide as many opportunities as possible to students to develop process skills. In developing process skills requires direct involvement of students in learning activities (Dewi et al., 2017). The direct learning process is an educational process in which students develop knowledge, thinking skills and psychomotor through direct interaction with learning resources designed in the syllabus and lesson plans in the form of learning activities.

IPA essentially includes four main elements, namely first, attitude: curiosity about objects, natural phenomena, living things, and causal relationships that cause new problems that can be solved through correct procedures, IPA. open ended; second, the process: problem-solving procedures through scientific methods; third, products: in the form of facts, theoretical principles, laws; and fourth, application: application of scientific methods and science concepts in everyday life (Luh \& Latria, 2018). That way, it is easier to integrate into local wisdom in the local area because IPA is more suited to the natural environment. Science learning will lead students to understand more about the importance of protecting the environment (Lestari, 2018). In addition, students will also be trained to be skilled in managing the environment, which then becomes a habit in their lives. In conducting the analysis, the informants in this study included one traditional figure, one community leader, one classroom teacher at SD Negeri 64/1 Muara Bulian. The informants in this study were selected because they have a line of relationship to find out more about how teaching materials are related to local wisdom (betangas tradition) in Mandiangin District, Sarolangun Regency to foster character in students. Qualitative interviews based on the experiences and views of informants on existing knowledge of teaching materials and local wisdom.

\section{The Use of Class V Elementary School Teaching Materials}

Local wisdom is learning through culture is a method that provides students with opportunities to demonstrate the achievement of understanding or meaning created in a subject through various cultural forms (Pratama et al., 2017). One of them is by analyzing the characteristics of high-grade elementary school children, namely regarding local wisdom which is often linked in learning activities around the school environment or local area. Local wisdom through the betangas tradition is still rarely used during learning activities, the teaching materials used are still glued to textbooks, pictures, and others. Books are the teaching material that is most often used during learning activities, even though it is not enough for children as young as fifth grade to deliver material if they only use books. Because it is a good teaching material that can attract students' interest in learning and make students happy when studying. In learning activities, teaching materials have a very important role, namely for students, teaching materials become reference materials that are absorbed by the content, so that they can become a source of knowledge, while for teachers, teaching materials become a reference in delivering knowledge / material to students (Hutama, 2016). The results of the analysis on theme 6 (Heat and Its Transfer) sub-theme 1 (Temperature and Heat) learning 1 
(Indonesian and IPA) content. The main material is in accordance with KD and in accordance with local wisdom taken, namely the typical betangas tradition of Mandiangin sub-district.

\section{Character of environmental care}

Environmental care character education can be developed for students so that they can wisely manage the natural resources around them, and to foster a sense of responsibility for the interests of the nation's next generation (Sulastri, 2017). In addition to fostering a sense of responsibility, students must be creative and serious in improving their quality. In line with Character in the form of personality qualities is obtained through an educational process that is taught seriously, seriously, consistently and creatively, which begins (Anisah, 2018). So that by having character we can develop positive values in ourselves and add broad insight by interacting with each other both with family and society. Character education teaches habits of thinking and behavior that help individuals to live and work together as a family, community and state and help them to make responsible decisions (Hemafitria, 2019). Based on the results of interviews with the traditional leader of Mandiangin, the betangas tradition can foster a caring character for the environment, such as cooperation in preserving the spices of the betangas tradition and maintaining the culture in the local area.

The objectives of character education for environmental care are: 1) Encouraging habits and with proper environmental management; 2) Increase the ability to avoid traits that can damage the environment; 3) Cultivate the sensitivity of students to environmental conditions so that they can avoid properties that can damage the environment; 4) To instill a caring and responsible spirit towards environmental sustainability (Nisa, 2015). With the goal of character education caring for the environment, students are more focused and guided. By preserving and instilling a spirit of caring for the environment will foster an attitude not to damage the environment but to participate in cultivating the culture that exists in the local area. Cultivating and developing character values in children is more appropriate if it is done early on and starting from the family environment, school, then the community (Ikawati \& Mustadi, 2018). Environmental factors greatly influence the character of students. Like in the family, the parents are role models for children at home. At school, the teacher becomes a role model for someone who is inspired and imitated by their students. In society, it also has an important role in the development of children's character.

The surrounding community environment clearly has a big influence and has a big share in the success of planting aesthetic and ethical values for the formation of the character of students (Mustika \& Sahudra, 2018). The indicators of environmental care include the attitude of wanting to always help others, appreciating differences, the attitude to carry out their duties and obligations, instilling a caring attitude towards the environment, and being able to socialize with the surrounding environment. With these indicators, it can make it easier for teachers to foster environmental care characters in students.

\section{Conclusions and Suggestions}

Based on the discussion, it can be concluded in analyzing the need for teaching materials based on local wisdom of the Mandiangin community as follows, namely teaching materials that have a broad material coverage that can be integrated with local local wisdom, can activate students both from the aspects of attitudes, knowledge and skills, the need for efforts from educators to develop teaching materials according to needs and raise existing local wisdom, and present learning activities that are in accordance with the demands of the 2013 curriculum with the 5M scientific approach (observing, asking, trying, reasoning and communicating). So that it can be arranged teaching materials based on local wisdom of the bathing community that are valid, interesting and effective for use in grade $\mathrm{V}$ Elementary School. Through character education, it is hoped that it can generate and realize environmental awareness. 


\section{References}

Afiqoh, N., Atmaja, H. T., \& Saraswati, U. (2018). Penanaman Nilai Kearifan Lokal dalam Pembelajaran Sejarah Pokok Bahasan Perkembangan Islam di Indonesia Pada Siswa Kelas X IPS di SMA Negeri 1 Pamotan Tahun Ajaran 2017/2018. Indonesian Journal of History Education, 6(1), 42-53. https://journal.unnes.ac.id/sju/index.php/ijhe/article/view/27353.

Anisah, N. (2018). Penanaman Pendidikan Karakter di Sekolah Dasar: Sebuah Tinjauan di SD Kedungpring, Pleret, Bantul. Abdau: Jurnal Pendidikan Madrasah Ibtidaiyah, 1(1), 5670. https://doi.org/10.36768/abdau.v1i1.6.

Aryanto, S., Markum, Pratiwi, V., \& Husadha, C. (2019). Ecobrick sebagai Sarana Pengembangan Diri Berbasis Ecopreneurship di Sekolah Dasar. Dwija cendekia: Riset Pedagogik, 3(1), 93-101. https://jurnal.uns.ac.id/jdc/article/view/34076/22647.

Ayu Shaleha, M., \& Purbani, W. (2019). Using Indonesian Local Wisdom As Language Teaching Material to Build Students' Character in Globalization Era. KnE Social Sciences, 3(10), 292. https://doi.org/10.18502/kss.v3i10.3910.

Azmi, Z., Nasution, A. A., \& Wardayani, W. (2018). Memahami Penelitian Kualitatif dalam Akuntansi. Akuntabilitas, 11(1), 159-168. https://doi.org/10.15408/akt.v11i1.6338.

Budi Setyaningrum, N. D. (2018). Budaya Lokal Di Era Global. Ekspresi Seni, 20(2), 102. https://doi.org/10.26887/ekse.v20i2.392.

Budiman, H. (2017). Peran Teknologi Informasi Dan Komunikasi Dalam Pendidikan. AlTadzkiyyah: Jurnal Pendidikan Islam, 8(1), 31. https://doi.org/10.24042/atjpi.v8i1.2095.

Damanik, H., \& Pakpahan, S. P. (2017). Menyiapkan Bahan Ajar Sekolah Ramah Anak. JINOTEP (Jurnal Inovasi dan Teknologi Pembelajaran): Kajian dan Riset Dalam Teknologi Pembelajaran, 1(1), 68-80. http://dx.doi.org/10.17977/um031v1i12014p068.

Damayanti, D., \& Nurgiyantoro, B. (2018). Local Wisdom as Learning Materials: Character Educational Values of Sundanese Pupuh. Journal of Education and Learning (EduLearn), 12(4), 676. https://doi.org/10.11591/edulearn.v12i4.9291.

Dewi, N. P. S. R., Wibawa, I. M. C., \& Devi, N. L. P. L. (2017). Kemampuan Berpikir Kritis Dan Keterampilan Proses Dalam Pembelajaran Siklus Belajar 7E Berbasis Kearifan Lokal. JPI (Jurnal Pendidikan Indonesia), 6(1), 125-133. https://doi.org/10.23887/jpiundiksha.v6i1.9476.

Fitriasari, S., \& Yudistira, R. (2017). Model Pembelajaran Pendidikan Pancasila dan Kewarganegaraan untuk Menumbuhkan Karakter Peduli Lingkungan Hidup Siswa. Prosiding Konferensi Nasional Kewarganegaraan III. http://eprints.uad.ac.id/9777/.

Hemafitria, H. (2019). Nilai Karakter Berbasis Kearifan Lokal Tradisi Tepung Tawar Pada Etnis Melayu Sambas. Jurnal Pendidikan Kewarganegaraan, 3(2), 121. https://doi.org/10.31571/pkn.v3i2.1435.

Hutama, F. S. (2016). Pengembangan Bahan Ajar Ips Berbasis Nilai Budaya Asing Untuk Siswa Sekolah Dasar. JPI (Jurnal Pendidikan Indonesia), 5(2), 113. https://doi.org/10.23887/jpi-undiksha.v5i2.8359..

Immaniar, B. D., Sumarmi, S., \& Astina, I. K. (2019). Pembelajaran Lingkungan Berbasis Kearifan Lokal dengan Model Experiential Learning. Jurnal Pendidikan: Teori, Penelitian, dan Pengembangan, 4(5), 648-653. http://dx.doi.org/10.17977/jptpp.v4i5.12431.

Indrawini, T., Amirudin, A., \& Widiati, U. (2017). Pengembangan Bahan Ajar Tematik Subtema Ayo Cintai Lingkungan Untuk Siswa Kelas IV SD. Jurnal Pendidikan: Teori, Penelitian, dan Pengembangan, 2(11), 1489-1497. http://dx.doi.org/10.17977/jptpp.v2i11.10181.

Juniartina, P. P. (2018). Pengembangan Bahan Ajar IPA Terpadu Berkarakter Peduli 
Lingkungan Tema "Konservasi" Berbasis Kearifan Lokal Untuk Mahasiswa Jurusan Pendidikan IPA. Wahana Matematika dan Sains: Jurnal Matematika, Sains, dan Pembelajarannya, 12(1), 42-53. http://dx.doi.org/10.23887/wms.v12i1.13841.

Latif, I. A., Riyadi, R., \& Saputro, D. R. S. (2019). The mathematics teachers' understanding of learning process based on 2013 curriculum 2017 revision. Journal of Education and Learning (EduLearn), 13(1), 140. https://doi.org/10.11591/edulearn.v13i1.9201.

Lestari, Y. (2018). Penanaman nilai peduli lingkungan dalam pembelajaran ilmu pengetahuan alam. Jurnal Pendidikan Ke-SD-An, 4(2), 332-337. http://dx.doi.org/10.30738/trihayu.v4i2.2238.g1502.

Lestariningsih, N., \& Suardiman, S. P. (2017). Pengembangan Bahan Ajar Tematik-Integratif Berbasis Kearifan Lokal Untuk Meningkatkan Karakter Peduli Dan Tanggung Jawab. Jurnal Pendidikan Karakter, 7(1). https://doi.org/10.21831/jpk.v7i1.15503.

Muhtar, T., \& Dallyono, R. (2020). Character Education from the Perspectives of Elementary School Physical Education Teachers. Cakrawala Pendidikan, 39(2), 395-408. https://doi.org/10.21831/cp.v39i2.30647.

Munir, E., Harefa, R. S. M., Priyani, N., \& Suryanto, D. (2018). Plastic degrading fungi Trichoderma viride and Aspergillus nomius isolated from local landfill soil in Medan. In IOP Conference Series: Earth and Environmental Science (Vol. 126, No. 1, p. 012145). IOP Publishing. https://doi.org/10.1088/1755-1315.

Mustika, F., \& Sahudra, T. M. (2018). Peranan Lingkungan Sosial terhadap Pembentukan Karakter Peduli Lingkungan Mahasiswa Pendidikan Geografi di Universitas Samudra Langsa. Jupiis: Jurnal Pendidikan IImu-IImu Sosial, 10(2), 235. https://doi.org/10.24114/jupiis.v10i2.11291.

Nisa, J. (2015). Outdoor Learning Sebagai Metode Pembelajaran IPS dalam Menumbuhkan Karakter Peduli Lingkungan. SOSIO-DIDAKTIKA: Social Science Education Journal, 2(1), 1-11. http://dx.doi.org/10.15408/sd.v2i1.1339.

Nurafni, A., Pujiastuti, H., \& Mutaqin, A. (2020). Pengembangan Bahan Ajar Trigonometri Berbasis Kearifan Lokal. Journal of Medives : Journal of Mathematics Education, 4(1), 71. https://doi.org/10.31331/medivesveteran.v4i1.978.

Oktariyani, \& Juwita, R. P. (2019). Analisis Kebutuhan Bahan Ajar Bahasa Inggris Berbasis Local Learning pada Siswa Sekolah Dasar. Jurnal IImu Pendidikan (JIP), 11(2), 95101. https://doi.org/10.37640/jip.v11i2.93.

Pratama, Y., Sariyatun, S., \& Joebagio, H. (2017). The development of Means-Ends Analysis and Value Clarification Technique Integration Model to explore the local Wisdom in Historical Learning. Journal of Education and Learning (EduLearn), 11(2), 179. https://doi.org/10.11591/edulearn.v11i2.5752.

Priyambodo, E., \& Wulaningrum, S. (2017). Using Chemistry Teaching Aids Based Local Wisdom as an Alternative Media for Chemistry Teaching and Learning. International Journal of Evaluation and Research in Education (IJERE), 6(4), 295. https://doi.org/10.11591/ijere.v6i4.10772.

Priyatna, M. (2017). Pendidikan karakter berbasis kearifan lokal. Edukasi Islami: Jurnal Pendidikan Islam, 5(10), 1311-1336. http://dx.doi.org/10.30868/ei.v5i10.6..

Putri, D. P., Zuhud, E. A., Hermawan, R., \& Tumanggor, R. (2017). The Diversity of Plants for $\begin{array}{llll}\text { Berangas } \quad \text { Materials. Media Konservasi, } & \text { 22(1), }\end{array}$ https://doi.org/10.29244/medkon.22.1.87-91.

Rachmadyanti, P. (2017). Penguatan Pendidikan Karakter Bagi Siswa Sekolah Dasar Melalui Kearifan Lokal. Jurnal Pendidikan Sekolah Dasar, 3(2), 201. https://doi.org/10.30870/jpsd.v3i2.2140. 
Rahayuningtyas, D. I., \& Mustadi, A. (2018). Analisis Muatan Nilai Karakter Pada Buku Ajar Kurikulum 2013 Pegangan Guru dan Siswa Sekolah Dasar. Jurnal Pendidikan Karakter, 8(2), 123-139. https://doi.org/10.21831/jpk.v8i2.21848.

Riwu, I. U., Laksana, D. N. L., \& Dhiu, K. D. (2018). Pengembangan Bahan Ajar Elektronik Bermuatan Multimedia Pada Tema Peduli Dasar Kelas Iv Di Kabupaten Ngada. Journal of Education Technology, 2(2), 56-64. https://ejournal.undiksha.ac.id/index.php/JET/article/view/16182/11495..

Santosa, A. B., Basuki, Y., \& Puspita, A. M. I. (2019). The Effectiveness of Local WisdomBased Teaching Materials in Enhancing Creative Writing Skills of Elementary School Students. Journal of English Language Teaching and Linguistics, 4(3), 349. https://doi.org/10.21462/jeltl.v4i3.326

Shufa, N. K. F. (2018). Pembelajaran Berbasis Kearifan Lokal Di Sekolah Dasar: Sebuah Kerangka Konseptual. INOPENDAS: Jurnal IImiah Kependidikan, 1(1). 48-53. https://jurnal.umk.ac.id/index.php/pendas/article/view/2316.

Sinulingga, E. B., Sitompul, H., \& Menanti, A. (2019). Pengaruh Strategi Pembelajaran dan Motivasi Berprestasi Terhadap Hasil Belajar Teknologi Informasi Dan Komunikasi (TIK). Jurnal Teknologi Informasi \& Komunikasi dalam Pendidikan, 6(1), 1-11. https://doi.org/10.24114/jtikp.v6i1.16934.

Sulastri, A. (2017). Peningkatan Keterampilan Menulis Deskripsi Melalui Penggunaan Media Gambar Berseri di Kelas IV SD Negeri 01 Daya Asri Kabupaten Tulang Bawang Barat. DWIJA CENDEKIA: Jurnal Riset Pedagogik, 1(1). 1-9. https://doi.org/10.20961/jdc.v1i1.13050.

Sumardjoko, B., \& Musyiam, M. (2018). Model of Civic Education Learning Based on the Local Wisdom for Revitalizing Values of Pancasila. Cakrawala Pendidikan, 37(2). 201-211. https://doi.org/10.21831/cp.v37i2.18037.

Wiratni, N. M. Y. (2017). Integrasi Budaya Lokal Dalam Muatan Sikap Pembelajaran Anak Kelas Tinggi Pada Tema Daerah Tempat Tinggalku. Jurnal Imiah Pendidikan dan Pembelajaran, 1(3), 208-218. http://dx.doi.org/10.23887/jipp.v1i3.11986. 